\title{
Crisis Management and Communication Experience in Education during the COVID - 19 Pandemic in Indonesia
}

\author{
DASRUN HIDAYAT \\ ARS University, Indonesia
}

ANISTI

Bina Sarana Informatika University, Indonesia

PURWADHI

ARS University, Indonesia

DARAJAT WIBAWA

Islamic State University of Sunan Gunung Djati, Bandung, Indonesia

\begin{abstract}
The focus of this research is crisis management in the education sector during the COVID-19 pandemic. This was done following an atmosphere of crisis in the field of education that encouraged the Indonesian government to issue policies in the form of the Study from Home ( $\mathrm{SfH}$ ) crisis programme. The object being analysed is related to the application of crisis management and the communication experience of students during the programme. The purpose of this study is to describe the opinions of students during the crisis programme. The study was conducted in the city of Bandung by involving lecturers and students. The methodology used is a qualitative approach to phenomenological studies. Data collection was conducted through online interviews and literature studies. The study found that the government established $\mathrm{SfH}$ as an emergency learning programme during the COVID-19 pandemic. The implementation of $\mathrm{SfH}$ was through online learning using various chat and video conference applications. There were two weaknesses of online learning namely technical and communication weaknesses. Technical weakness is influenced by geographical factors, internet networks, and internet costs. While communication weaknesses include slow adaptation, learning media are not optimal, and an interactive atmosphere has not been developed, and there is no atmosphere of empathy. This situation results in lecturers not being able to manage the learning effectively. Studying online during $\mathrm{SfH}$ should be able to build collaboration classes to be able to foster motivation and interest in student learning. Collaboration classes are realised when lecturers and students try to improve communication competencies.
\end{abstract}

Keywords: COVID-19, crisis management, communication experience, online learning, study from home.

\section{INTRODUCTION}

A Study from Home $(\mathrm{SfH})$ is a crisis programme in the education sector. This policy was implemented during the COVID-19 pandemic. Handling in times of crisis applies to all institutions including educational institutions. Although the handling of the crisis is technically given to each institution (Wajdi et al., 2020). A crisis is an unfavourable situation so it needs to be dealt with together. A Crisis can also be interpreted as an event that will have negative implications on the organisation or company (Fajar, 2011). COVID-19 is an unexpected situation because it harms all sectors including social, cultural, educational, political, legal, 
and security. There needs to be a response to the COVID-19 crisis. Comprehensive handling is called crisis management. Smith explained that crisis management is a treatment that must be done given the issues outside the control of the institution or company (Smith, 2005). Crisis handling consists of three stages, namely pre-crisis, crisis, and post-crisis (Sa'diyah, 2013). Precrisis can be interpreted as an initial effort that must be done by the institution to collect data related to the crisis issue and identify problems. The crisis programme is the handling stage in the form of implementing a programme strategy. This strategy correlates with the identification of problems as the basis for establishing a crisis programme. The next stage of crisis management is post-crisis. This stage aims to measure the process of implementing a crisis programme.

The government has carried out all stages of crisis management in the education sector. The policy is an effort to deal with COVID-19 emergency conditions. Handling starts from an inventory of the problems faced following the occurrence of the COVID-19 pandemic. In the next step, the government issued a crisis programme in the form of a Study from Home $(\mathrm{SfH})$. This programme is a type of distance learning activity or a study from home. Distance learning uses internet-based technology so it is called online learning. Online technology is expected to be a solution for learning media during the COVID-19 pandemic. During $\mathrm{SfH}$, the government also conducts monitoring and evaluation. This step is a manifestation of the final stages in crisis management.

Monitoring as the final stage of crisis management is indeed very necessary. Monitoring to measure the success of online learning systems. To know the online learning process, opinions are needed directly from the users of online learning media. Among these are students who almost every day do online learning. Of course, these online learning activities produce a lot of communication experiences. Experience is based on motives to produce different perceptions of reality (Nurtyasrini \& Hafiar, 2016). The intended reality is the reality of online learning during the COVID-19 pandemic. The crisis is still ongoing so online learning also continues. During that time students also have various experiences when participating in online learning. The experience is interesting to study and explain in a scientific article. It is hoped that the results of this study will be able to contribute to the implementation of the Study from Home crisis programme during the COVID-19 pandemic.

Student's communication experience is the perceived output after attending the Study from Home ( $\mathrm{SfH}$ ) programme. Experiences include knowledge, feelings, interests, and behaviour. Cognitive experience means that communication has an impact on one's knowledge. An affection experience is a level of experience not only knowledge but also feelings, interests, or emotions. The highest level of experience is the experience of communication behaviour. Behaviour is based on individual experiences that are usually attached to a particular event (Fitriyani, 2018). Experience also creates better relationships because each individual learns from experience (Mardhiyani, 2014). Experience not only influences knowledge and interests but also encourages someone to act on the encouragement of communication activities. This is consistent with the results of previous studies, that communication experience was born because of communication activities consisting of actions, speech, and interactions (Nurtyasrini, Hafiar, 2016). Communication activities are a prerequisite for each individual in building social existence. Communication experience is built because of a series of phenomena that can influence action (Prihandini, 2016). Communication plays a very important role in creating communication experiences (Venus \& Nabilah, 2016). 
The communication experience referred to in this article is the communication experience of students in conducting online learning during the COVID-19 pandemic. Online learning policy as an implementation of the Study from Home (SfH) programme. This policy aims to break the COVID-19 chain in Indonesia. The SfH policy is applied to all levels of education, from Early Childhood Education (PAUD), Kindergarten (TK), Elementary School (SD), Junior High School (SMP), Senior High School (SMA), and Higher Education (PT). SfH is expected to be able to assist the learning process during the COVID-19 pandemic. SfH through internet technology-based learning is considered as one solution to maintaining the learning process. Online learning is also called e-learning. By definition, e-learning is defined as learning activities that require and use Information Communication and Technology or ICTbased devices (Churton, 2006). Online-based learning is considered as a learning device that can be used as a media support (Nuriyanti, Utami, \& Supriyanto, 2013). Online learning media have various choices, ranging from sending messages to video conferencing media. All online learning platforms offer a variety of interesting features. These features can facilitate online learning. However, the $\mathrm{SfH}$ programme by implementing online learning still requires a process of monitoring and evaluation.

Monitoring is intended to monitor the implementation of the Study from Home $(\mathrm{SfH})$ crisis programme. While the evaluation is the final part to find out the effectiveness of the implementation of the crisis programme. The activity was the foundation of the research objective which was to find out the experience of students regarding the implementation of $\mathrm{SfH}$ as a crisis programme in education during the COVID-19 pandemic. The experience is related to the weaknesses of the implementation of the $\mathrm{SfH}$ crisis programme by implementing an online learning system. The research also aims to describe the communication competencies of lecturers and students when studying online. Communication competence determines the effectiveness of learning. Among the readiness of lecturers and students when doing online learning greatly affects the final learning outcomes. The variety of results from the objectives of this study are expected to provide an overview related to the evaluation of $\mathrm{SfH}$ policy implementation. This can be used as a reference for the Indonesian government when it will issue new policies related to learning scenarios in the new normal era during the COVID-19 pandemic.

\section{LITERATURE REVIEW}

\section{a. Crisis Management in the Education Sector}

Crisis management is an emergency response strategy. This situation can occur in every institution, organisation, and company, both private and government institutions. A Crisis can happen anytime and anywhere. When a crisis occurs, of course, it will have an impact on the company. In the context of this study, the handling of the crisis in question is the crisis caused by the COVID-19 pandemic. Since COVID-19 occurs all sectors have been paralysed, starting from the economic, political, socio-cultural, and education sectors. This situation occurs in several countries in the world including Indonesia. It was noted that Indonesia began to be exposed to COVID-19 on 16 March 2020. The first case occurred in the city of Depok involving parents and children. COVID-19 continues to plague until finally, the government establishes the emergency status of COVID-19. This condition is then handled by the government by implementing a crisis management programme. By definition, a crisis can be interpreted as an abnormal situation. This situation can threaten the existence of institutions (Luhukay, 2013). A crisis is an unexpected situation. Institutions or companies, in general, cannot expect 
the crisis to occur. As a threat, the crisis must be dealt with quickly so that the institution or organisation can return to normal. This is in line with the understanding of the crisis according to Kathleen Fear-Banks, that the crisis is interpreted as an event that will have negative implications (Fajri \& Mawadati, 2018). What is meant by crisis management is when efforts are made to deal with a crisis. It needs to deal with it as soon as possible when the privation, and the company is experiencing a crisis.

The crisis management that will be discussed in this article is a crisis management effort that has been made by the Indonesian government in handling the COVID-19 pandemic. This article focuses on discussing crisis management in the education sector. Handling by the government related to the implementation of learning during the COVID-19 pandemic. The Indonesian government has issued a policy crisis programme called Study from Home.

\section{b. Communication Experience}

Communication experience is a statement of someone after experiencing an event. In the context of this research, the intended event is a student's communication event when participating in the Study from Home programme during the COVID-19 pandemic. How they say related communicative actions during learning. Communication experience can also be interpreted as reflection or thinking based on memory (Hidayat, 2012). Communication experience is also identical to an event (Fitriyani, 2018). Previous research found that a person's experience can make him better or create a better relationship (Mardhiyani, 2014).

Communication experience in principle can be shared with others. If other people also have the same experience, a mutual agreement will be developed among individuals (Yayu, Hidayat, \& Suhadi, 2019). Communication experience occurs because of communication activities. Previous research also revealed that communication experience was born because of communication activities consisting of actions, speech, and interactions (Nurtyasrini, Hafiar, 2016). These communication activities are a prerequisite for each individual in building social existence (Hidayat, Kuswarno, Zubair, \& Hafiar, 2018). Communication experience is built because of a series of phenomena that can influence action (Prihandini, 2016). Communication plays a very important role in creating communication experiences (Venus \& Nabilah, 2016).

\section{c. Study from Home}

The crisis learning programme during the COVID-19 pandemic is called Study from Home. This policy is implemented through distance learning using an online system. Online learning is explained as open learning that is distributed through the internet network or web-based network. This system intends to facilitate learning and knowledge development through distance learning activities (Fitri \& Putra, 2019). E-learning is considered as an innovation that has contributed greatly to changes in the learning process. The learning process is no longer just listening to the material description from the teacher, but students also carry out other activities such as observing, doing, demonstrating, and others (Rahardja, Lutfiani, Handayani, \& Suryaman, 2019).

The development of learning media based on e-learning aims to minimise the difficulties of students and lecturers in learning activities. These difficulties are mainly due to psychological, geographical, and time issues (Cyly, Dalu, \& Rohman, 2019). One online learning theory is Online Collaborative Learning (OCL). Linda Harasim as the originator of the theory explains that internet facilities aim to provide a learning environment and foster collaboration to build knowledge. Harasim described $\mathrm{OCL}$ as a new learning theory that 
focuses on collaborative learning (Picciano, 2017). E-learning in the context of this study is a learning system that was implemented during the COVID-19 pandemic. This learning is a form of crisis programme called Study from Home.

\section{d. COVID-19}

Coronavirus including superdomain biota, kingdom virus. Coronaviruses are the largest group of viruses in the order Nidovirales. All viruses in the order Nidovirales are non-segmented positive-sense RNA viruses (Beniac, Andonov, Grudeski, \& Booth, 2006). The coronavirus belongs to the Coronaviridae family, the Coronavirinae sub-family, the genus Betacoronavirus, the Sarbecovirus subgenus. Virus grouping was initially sorted into serology based groups but now based on phylogenetic grouping. It was further explained that the Sarbecovirus subgenus included Bat-SL-CoV, SARS-CoV, and 2019-nCoV. Bat-SL-CoV was originally found in Zhejiang, Yunnan, Guizhou, Guangxi, Shaanxi, and Hubei, China (Beniac et al., 2006).

Coronavirus is considered a contagious and deadly virus. The working system of this virus attacks the respiratory tract to the lungs. In general, people with COVID-19 will experience early symptoms such as fever, sore throat, runny nose, and cough can even cause pneumonia (Yunus \& Rezki, 2020). COVID-19 can be transmitted by direct contact close to people with COVID-19. Wuhan, the capital of Hubei Province in central China, is the first province to be exposed to COVID-19. In early December 2019, a patient was diagnosed with unusual pneumonia. On December 31, the World Health Organisation (WHO) regional office in Beijing received a notification about a group of patients with pneumonia whose cause was unknown from the same city (Emma \& Arina Anis, 2020). Infectious diseases spread globally. Among the countries exposed to COVID-19 are China, Italy, the United States, Spain, France, Malaysia, the Philippines, Thailand, and including Indonesia.

The Indonesian government is currently making efforts to break the chain of COVID19 distribution through quarantine policies and increase social distancing activities (Telaumbanua, 2020). Even as of April 2020, the government has implemented the status of Large-Scale Social Restrictions (PSBB). This policy aims to maintain distance when interacting with the surrounding community. Besides, people who will leave the house are asked to wear masks. This policy is a global policy that has been implemented in exposed countries. COVID19 has also a very big impact, especially on educational activities. Nearly all over the world, run a learning policy from home or implement distance learning through an online learning system. It happens to employees or workers, asked to do activities from home as well.

PSBB policy is another term for lockdown. In the beginning, this policy caused public anxiety. The policy is considered to be difficult for the community in carrying out its activities and mobility. However, the government's decision cannot be changed, to stop the spread of COVID-19. PSBB is an extension of social distancing that covers certain areas. If an area or region has implemented the status, then the local government has the right to close the entrance and exit for the community. Of course, PSBB policies, lockdowns, or the like are taken into consideration, especially related to budget readiness and social impacts that arise (Yunus \& Rezki, 2020).

Over time and the increasing number of COVID-19 pandemic patients, the Government of Indonesia is now firmly requesting all institutions and companies to follow the rules, which is to close their operational activities. This is expected to break the spread chain of the COVID-19 virus. However, this policy will indirectly have an impact on the economy. 
The markets will be empty, traders will also be empty, there are no direct transactions because many people who carry out activities at home. Companies and small-scale industries will also suffer losses due to the COVID-19 pandemic.

\section{RESEARCH DESIGN}

This study on crisis management and communication experience in education in Indonesia uses phenomenological studies. Researchers use phenomenology because it aims to construct the experience of lecturers and students during the Study from Home $(\mathrm{SfH})$ crisis programme. In this case, the researcher tried to focus on three aspects, namely ontology, epistemology, and axiology. Ontology is a description of students' experiences in explaining the reality of online learning as a form of Indonesian government policy in the form of the SfH programme. While in epistemology, researchers conducted in-depth data mining. The data collection techniques used by researchers are interview techniques and documentation review. Interviews were conducted online via WhatsApp and email. This technique was taken considering that the physical distancing status is still in effect. Interviews with 23 informants consisted of 2 key informants and 21 main informants. Key informants were drawn from education observers, while the main informants were from lecturers and students in the city of Bandung. Informants were taken purposively with the criteria of carrying out online learning during the COVID-19 pandemic. Meanwhile, the documentary review was sourced from mass media and internal campus media news.

Another reason researcher use phenomenology is that the axiology of research on crisis management and communication experience aims to construct the experiences of lecturers and students in implementing online learning. It is hoped that this experience can build a joint consensus related to communication experience following the $\mathrm{SfH}$ programme during the COVID-19 pandemic.

Schutz (in et al. 2016) theoretically interpreted phenomenology as an understanding of speech, action, and interaction. These aspects are a condition for each individual in carrying out social existence. According to Schutz, human actions are part of their position in society, so that one's actions can be the result of imitating the actions of others around people (Nurtyasrini \& Hafiar, 2016). In the context of this study, the experience of each individual could have been emerged because of learning and seeing the surrounding environment. Perceptions about online learning while participating in the SfH programme are constructed and shared with other students to produce a shared agreement on communication experiences when studying online.

The first, second, and third stages of the data construct are the data analysis techniques used in this study. The term data construct refers to the reduction, display, and conclusion drawing (Hidayat, Hafiar, \& Anisti, 2019). The first data construct phase of the researcher conducted a selection of interview data. The interview data taken is data that is relevant to the purpose of the research, namely the experience of students related to the implementation of monitoring, evaluation, and communication competence during online learning. The results of data selection are then made into data categorisation that refers to aspects of the research question. This categorisation aims to make it easier for researchers to find important points by the question. The method used is to highlight the data based on the results of data selection. Highlights are short excerpts from interviews with informants that are presented in the results of research and discussion. While in the third stage, researchers make data analysis taken from highlight data. Analysis refers to relevant theories or 
constructs axioms, assumptions of new theories to strengthen the previous theory. This stage is also called the term of conclusion drawing.

\section{RESULTS AND DISCUSSION}

\section{a. A Study from Home as the Policy of Covid-19 Crisis Programme}

Government policy requires all activities to be carried out from home without exception, including in education by creating a Study from Home $(\mathrm{SfH})$ system. This step was taken to overcome the crisis in the field of education during the COVID-19 pandemic. A crisis can be interpreted as a situation that is not wanted so it must be overcome so as not to interfere with other systems (Luhukay, 2013). According to students, the crisis programme policy in the form of SFH must indeed be taken by the government to break the Covid-19 chain. "It is an emergency, so you learn from the house as the choice". Another expression was explained by the lecturer that online learning is quick action by the government in dealing with crisis due to the COVID-19 pandemic. "It is appropriate that this policy is implemented to help the government stop corona exposure".

The SfH policy is inevitable and must be done by students at all levels, from kindergartens to tertiary institutions. However, $\mathrm{SfH}$ implies that learning is done remotely using an online classroom system. "We have been studying online for a few weeks, and we don't go to a campus anymore". Students generally know the concept of online classes. They explained that online classes are learning using internet-based technology. "We already knew that the online system was before the existence of COVID, but the difference now is that it continues online, we use the internet online". Technology-based learning is also referred to as learning by applying Information Communication and Technology (Churton, 2006). For lecturers and students using technology in learning is not a difficult thing to do even though this method has only been applied. This situation is supported by the ability of those who are accustomed to using technology as communication media daily. However, after the Covid-19 pandemic, the technology was used in addition to communication media as well as online classroom learning media. This is as revealed by key informants as education observers that technically mastery of technology has not become an obstacle, but the ability to manage online communication must be improved. "The emphasis is on communication skills or abilities when learning online, this is very different from learning in the classroom". The informant's acknowledgement was in line with communication competence, namely the ability to communicate well (Nuredayu, 2018). This ability should be prepared from the beginning so that lecturers and students are ready to do online learning.

In general, lecturers and students know the government policy in breaking the Covid19 chain is from the mass media channel. They acknowledged that the information was very easy to obtain because the government provided a special channel regarding COVID-19 information in the form of TVRI broadcasts and the website of the Ministry of Communication and Information of the Republic of Indonesia. This situation was recognised by the informants as a form of public information disclosure. "Always know about the latest news of COVID because the government provides official channels, and that is very helpful". In line with the key informant's statement that information has become a public need, the government must prepare the ingredients. "The government has prepared all the media to access COVID-19 information". This openness requires the public to acknowledge that they have easy access to information (Ahmadi, Rachmiatie, \& Nursyawal, 2019). This is also the case with the current 
pandemic situation, that the government must provide easy and credible media channels so that it can help break the COVID-19 chain.

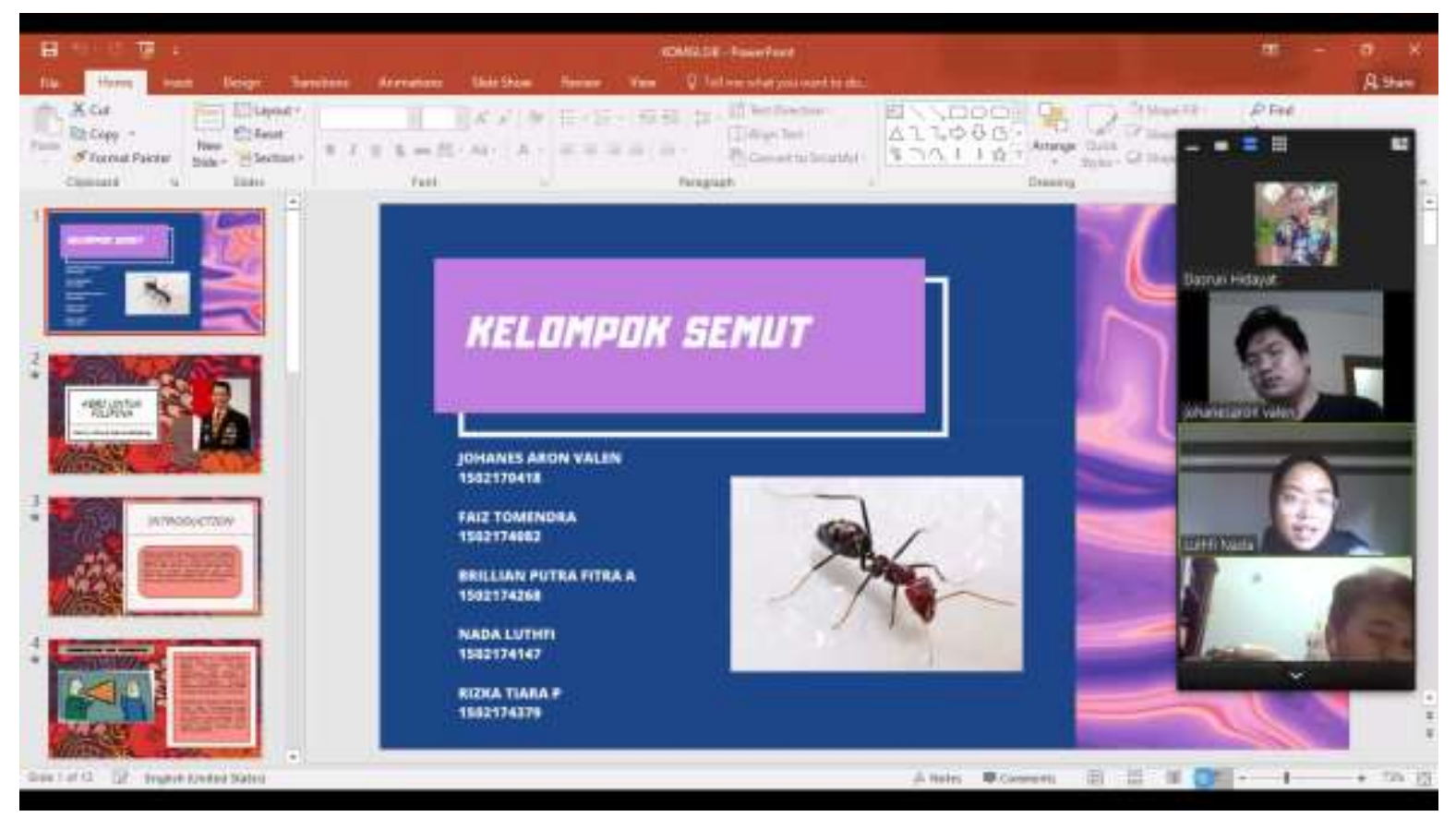

Figure 1: Online learning situations during the COVID-19 pandemic Source: Research Results

Information about Covid-19 is also accessed from social media. According to informants, social media is very fast and updates convey Covid-19 information. "Besides official channels, we also often follow the information on Instagram and What's App media". The presence of social media has indeed changed the behaviour of public communication, including the practical behaviour of accessing information. Social media is also able to change the way of thinking of each individual. This is in line with previous research which states that social media changes the communication paradigm. The message process is delivered without being limited by time and space. Everywhere, anytime, every individual can access information or communicate (Watie, 2016). Student orientation in choosing social media to access COVID-19 information is also based on friendship.

\section{b. $\quad$ The experience of students who are studying online during COVID-19}

From the middle of March 2020, the government has implemented the Study from Home $(\mathrm{SfH})$ policy. This policy applies to all levels of education, from early childhood education to tertiary education. $\mathrm{SfH}$ is a sequential treatment of learning during the coronavirus pandemic or COVID-19. SfH is implemented through online learning based on internet technology. Learning online by using various chatting and video conference applications. However, the weakness of this policy is that it cannot be applied evenly given that each region has different geographical characteristics. In some areas have difficulty getting an internet network. Another weakness found in the form of communication skills of lecturers and students.

Changes in the learning system from the initial face-to-face in the classroom to online certainly have implications for student communication behaviour. Those who were previously accustomed to communicating directly with lecturers or classmates then turned to virtual communication. The students admitted that behaviour change gave birth to new habits, such 
as communicating, using laptops or smartphones. Greet lecturers and friends from a distance, so emotionally less familiar. Besides, students also have difficulty in capturing nonverbal messages, such as body language, facial expressions, and others. "It's not fun learning online, I can't see the body language of friends and lecturers". A similar phrase is also said that online learning is less dynamic because it is limited by online time. "Difficulties in collaborating, interacting with friends and lecturers are limited". Students acknowledge that the limitations of online learning have not yet created a collaboration class. Though collaboration is needed to foster motivation and interest in student learning. This informant's confession was expressed in a study that explained that the communication behaviour of lecturers largely determines the ability of students to receive material in class. For example, a smiling lecturer can be interpreted by students that the teacher is showing a happy expression. Teachers who always make eye contact with students, in turn, are interpreted that teachers pay attention to all students (Sitompul, 2012).

Online systems make learning situations more complicated. This situation is felt by students when they have to get used to doing the assignments of each subject and added the deadline of the assignment simultaneously. "There are lecturers who disproportionately replace meetings with assignments, even though the material has not been explained yet". The complexity increases when they have to do the task independently without any discussion partners such as face to face learning in class. The explanation time for the material which is a bit involved in the discussion time is also limited interactive. The readiness of the material in the form of instructional media is also considered not optimal. "Students want interactive media to explain each lecture material". This acknowledgement proves that every lecturer must have a good intention when they start learning. This helps the learning process by using ICT technology (Abdul Ghafarmansor, Syed Zulkarnain \& Amani Ali, 2018). Online learning should not reduce the advantages of face-to-face learning that has the distinctiveness of being familiar and able to build student learning motivation. This atmosphere illustrates that students have not been able to adapt to the atmosphere of online learning.

The above research results are in line with the results of previous studies which state that online learning makes it difficult for students to hold discussions as a form of material deepening. For students, online discussions have many time limitation (Mastuti, 2016). The portrait experienced by these students illustrates that students are not ready to follow the elearning method or online learning. Whereas e-learning teaches independence to students because e-learning can foster learning motivation (Sari, 2015). Other research also suggests the same thing that the challenges of online learning teachers must be able to foster student learning motivation (Rahardja et al., 2019). One theory that can build motivation is the Online Collaborative Learning $(\mathrm{OCL})$ theory. This theory focuses on optimising the internet as a medium of collaborative learning between teachers and students (Picciano, 2017). This theory is relevant to The Technological Pedagogical Content Knowledge (TPACK) theory. Theories that explain the need for learning media based on Information Communication and Technology or ICT to build learning motivation (Koehler, Mishra, Akcaoglu, \& Rosenberg, 2013). Motivation to learn grows because of the driving factors both from within students (intrinsic) and from the surrounding environment (extrinsic) such as school friends and teachers. External factors generally hold a larger portion because the environment can influence student internal factors. For example, a student who is lazy to learn, find it difficult to understand the material. However, because of friendship at school, these difficulties can 
turn into students' motivation. He or she will spur himself/ herself to better by utilising the time of discussion both with friends and with class teachers.

Another experience about the complexity of students learning with an online system that is in the form of an internet network. Networks are built through cables and twigs that are connected to a computer system (Sari, 2015). This internet in principle produces signals that can be utilised by network users. However, the weakness is not all regions get the same strong signal. There are even some areas that cannot get internet signals. This situation is influenced by different geographical factors in each region. For example, the signal is difficult because in that area there are many towering buildings, bad weather, and even in that area, there are no internet cables and satellite installed. Some of these possible factors were raised by students. They said that the main obstacle when studying online was an unstable internet network. These technical problems cause communication messages to be delayed and even forced to disconnect the communication channels. "Online is limited in its network and is being chased by time, not getting everything to ask the teacher". This situation is recognized by the students' very disturbing concentration of learning and even raises feelings of anxiety. The experiences of these students have also been revealed in previous research that measures the evaluation of student learning outcomes by using an online system. The study found the same thing that is one of the factors that makes students lose concentration when facing signals or internet networks that are not optimal (Mastuti, 2016). Besides networking, students also complained about the cost of online because they have to prepare an internet quota every day. Also, they feel disturbed following the information about online applications that are not safe to use. Therefore, students suggest that the government makes special applications so that security is more controlled.

Less optimal communication skills and internet network systems in online learning have resulted in an ineffective learning atmosphere. Some problems felt by students can be concluded as communication weaknesses. This weakness occurs because communication skills are still lacking. Communication skills are often referred to as communication competencies. Good communication skills are needed especially in pandemic situations that force online learning. Weak communication competencies have resulted in not yet developed interactive and collaborative classes. This class builds when there is learning proportionally based on empathy. Efforts to feel and put themselves in the position of others in this case the situation of students (Yayu et al., 2019). Besides, good intention is needed for both lecturers and students to create effective learning. 


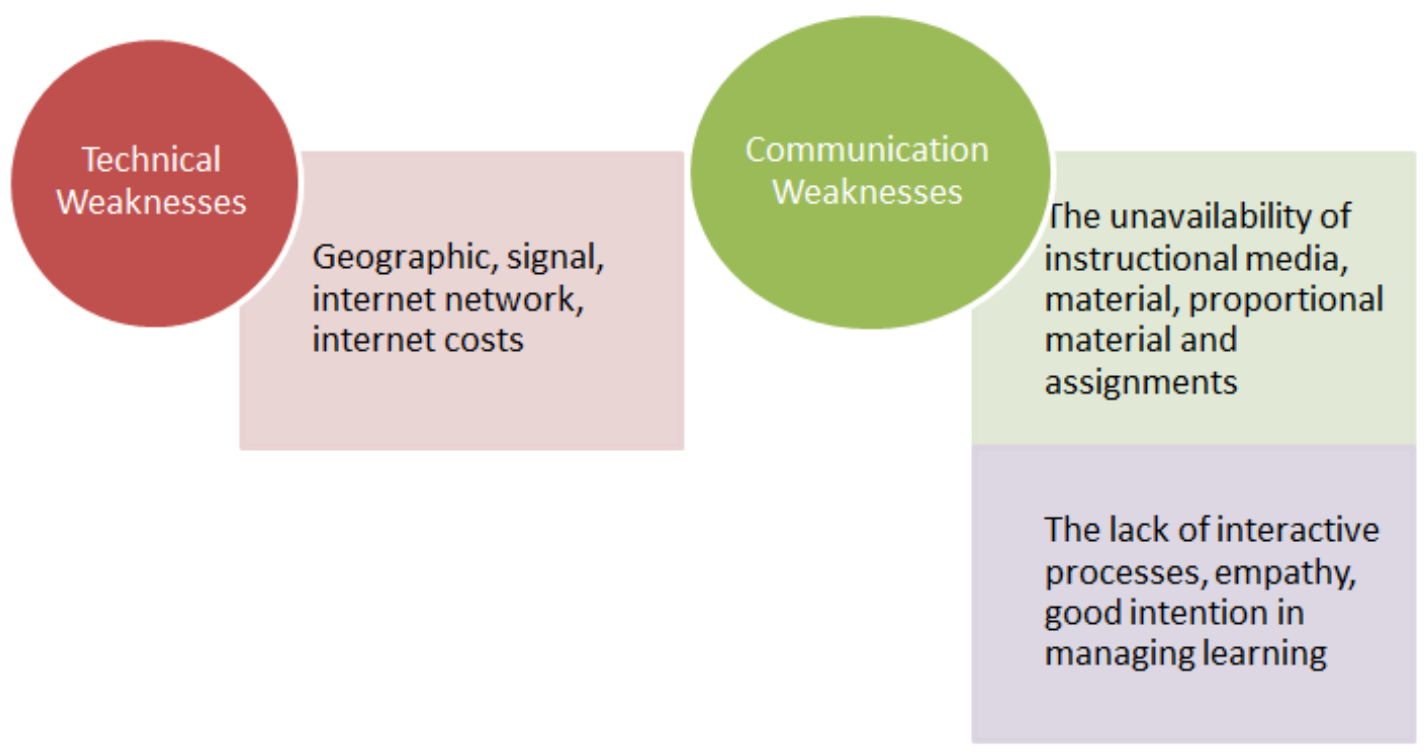

Figure 2: Online learning experiences during the Covid-19 pandemic Source: Research Results

The various weaknesses faced by students in the online learning process during the coronavirus pandemic or COVID-19 certainly become a challenge for lecturers and students. The hardest challenge of learning online in the digital age is creating a home atmosphere like a learning atmosphere in school (Hutchison, Paatsch, \& Cloonan, 2020). Cooperation is needed so that the learning atmosphere is conducive. Cooperation can strengthen collaborative learning systems. Characteristics of collaboration that is the interaction of educators and students during the learning process. Collaboration means students actively participate in learning. This collaboration is indeed a challenge because in principle online classes open opportunities for students to not actively interact. Even if there is interaction, the intensity and duration are less than that of direct classroom learning. Therefore, these interaction opportunities must be managed and utilised optimally.

To answer these challenges, lecturers and students must work together to improve communication competence. Based on the results of research that online learning communication competencies are not too different from learning directly in the classroom. However, the online learning process is more emphasised in the aspects of empathy. Efforts to make lecturers and students respect each other's roles and obligations. Empathy can be interpreted as an attitude that puts itself in the position of others (Yayu et al., 2019). Empathy in the online learning process means both show the ability to understand each other's situation. When online is felt heavy because of interference, then all parties should support each other to eliminate the interference. In addition to empathy, other aspects that can build competency in online learning communication are the ability to show good intentions, adaptability, interactive ability, and ability to manage the learning process. 


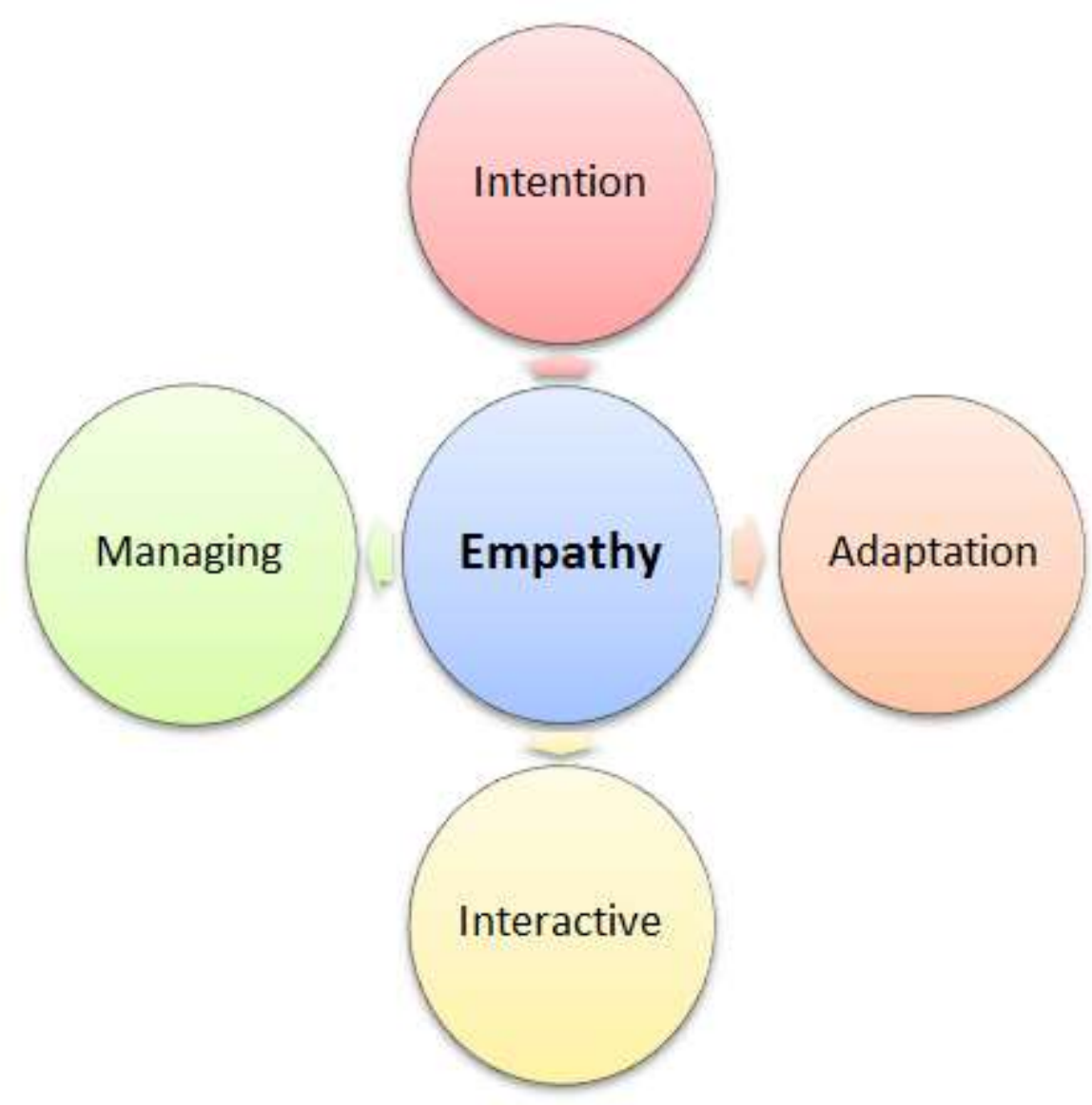

Figure 3: Competencies of online learning communication

Source: Research Results

The ability to show good intention starts with the attitude of empathy. Good intention means the effort to show supportive behaviour (Abdul Ghafarmansor, Syed Zulkarnain \& Amani Ali, 2018). Online learning works effectively when lecturers and students try to give their best by supporting each other's learning processes. In good intention emotionally there is no feeling of being burdened. For example, lecturers with a self-awareness that they must produce interesting learning materials. They also tried to convey the material clearly and concisely. Likewise, students try to complete their responsibilities, namely learning and doing each learning task. The existence of good intention indirectly builds a cooperative attitude so that it emerges the comfort of learning. The comfort of course will encourage students the confidence to discuss or create an interactive atmosphere. Every aspect must be managed to start with empathy, intention, adaptation, and interaction. The ability of lecturers and students to manage the learning time, material, interactive, and assignments proportionally. The ability to manage aspects of online learning is expected to encourage the creation of good relations (Nuredayu, 2018). Good relations occur when there are empathy and good intention together in the online learning process.

\section{CONCLUSION}

There are two weaknesses of online learning as the implementation of the Study from Home (SfH) crisis programme in Indonesia. Weaknesses consist of communication and technical weaknesses. Communication weaknesses occurred when lecturers did not prepare the 
learning material, not explain the material interactively, and there was no empathy atmosphere in the learning process. This weakness was caused by lecturers who have not maximised yet in implementing effective learning. Therefore, communication competencies between lecturers and students are needed while implementing the learning process. Communication competence uses the ability of empathy, the ability to show good intention, adaptation, interactive, and the ability to manage all aspects of learning including learning time, material, discussion, and learning assignments. Besides, there are also technical weaknesses, such as internet network systems, increasing the cost of internet quotas. It also felt very disturbing to the concentration of students when doing the learning. An increase in communication competency and the quality of the internet network is expected to be able to build good relationships so that learning can run effectively.

A Study from Home $(\mathrm{SfH})$ is a crisis programme in education during the COVID-19 pandemic. This programme aims to assist the Indonesian government in breaking the chain of the deadly virus. The implementation of $\mathrm{SfH}$ consists of online learning using a variety of internet-based applications.

The results of this study can of course still be developed, because each region has different characteristics. However, the results of this study are expected to make an appropriate contribution as the reference material for the Indonesian government in determining learning policies in the new normal era in the middle of the COVID-19 pandemic.

BIODATA

Dasrun Hidayat has written a book titled Interpersonal Communication and the Media, Media Cyber Public Relations, and Be a Good Communicator. Recently he also published an article on cultural public relations, namely cultural studies with a public relations theory approach. Email: dasrun@ars.ac.id

Anisti, a lecturer at the Faculty of Communication and Language, University of Bina Sarana Informatika, Jakarta. She recently published an article about local product branding strategies. Email: anisti@bsi.ac.id

Purwadhi, completed his doctorate in education. He is a teaching staff at the Universitas Adhirajasa Reswara Sanjaya (ARS University) graduate management programme. Email: purwadhi@ars.ac.id

Darajat Wibawa, lecturer in the Faculty of Communication and Da'wah, Islamic State University of Sunan Gunung Djati, Bandung, Indonesia. Email: darajatwibawa@uinsgd.ac.id 


\section{REFERENCES}

Abdul Ghafarmansor Mohamad, Syed Zulkarnain Syed Idrus, \& Amani Ali Elmetwely Ali Ibrahim. (2018). Model of behavioral attention towards using ICT in universities in Libya. Jurnal Komunikasi: Malaysian Journal of Communication, 34(2), 89-104. http://doi.org/10.17576/JKMJC-2018-3402-06

Ahmadi, D., Rachmiatie, A., \& Nursyawal. (2019). Public participation model for public information disclosure. Jurnal Komunikasi: Malaysian Journal of Communication, 35(4), 305-321. http://doi.org/10.17576/JKMJC-2019-3504-19

Beniac, D. R., Andonov, A., Grudeski, E., \& Booth, T. F. (2006). Architecture of the SARS coronavirus prefusion spike. Nature Structural and Molecular Biology, 13(8), 751-752. http://doi.org/10.1038/nsmb1123

Churton, M. W. (2006). Principles of e-learning and online teaching. Jurnal Pendidikan Terbuka Dan Jarak Jauh, 7(1).

Cyly, Z., Dalu, A., \& Rohman, M. (2019). Pengembangan e-learning sebagai media pembelajaran simulasi dan komunikasi digital bagi siswa SMK. Jurnal Pendidikan Teknik Elektro, 4(1), 25-33.

Emma Mohamad, \& Arina Anis Azlan. (2020). COVID-19 and communication planning for health emergencies (Correspondence Item). Jurnal Komunikasi: Malaysian Journal of Communication, 36(1).

Fajar, A. (2011). Sistem kendali dan strategi penanganan (manajemen) krisis dalam kajian public relations. Jurnal ASPIKOM, 1(3), 279. http://doi.org/10.24329/aspikom.v1i3.25

Fajri, C., \& Mawadati, S. (2018). Manajemen krisis pemerintah Kabupaten Kulon Progo. Jurnal ASPIKOM, 3(4), 783. http://doi.org/10.24329/aspikom.v3i4.224

Fitri, H., \& Putra, R. B. (2019). The impact of learning culture on readiness to online learning through learning satisfaction as intervening variable the industrial era 4.0. Jurnal Apresiasi Ekonomi, 7(3), 309-316.

Fitriyani, A. (2018). Fenomena komunikasi multikultural di kotta ambon: Studi pengalaman komunikasi antara etnik Bugis dan etnik Ambon. Dialektika; Jurnal Pemikiran Islam Dan IImu Sosial, 11(1), 228-235.

Hidayat, D. (2012). Komunikasi antarpribadi dan medianya (1st ed.). Jogjakarta: Graha Ilmu. Retrieved from http://www.grahailmu.com

Hidayat, D., Hafiar, H., \& Anisti. (2019). Tofu product branding for culinary tourism of Sumedang, Indonesia. Komunikator, 11(2).

Hidayat, D., Kuswarno, E., Zubair, F., \& Hafiar, H. (2018). Public relations communication behavior through a local-wisdom approach: The findings of public relations components via ethnography as methodology. Jurnal Komunikasi: Malaysian Journal of Communication, 34(3), 56-72.

Hutchison, K., Paatsch, L., \& Cloonan, A. (2020). Reshaping home-school connections in the digital age: Challenges for teachers and parents. E-Learning and Digital Media, 17(2), 167-182. http://doi.org/10.1177/2042753019899527

Koehler, M. J., Mishra, P., Akcaoglu, M., \& Rosenberg, J. M. (2013). The technological pedagogical content knowledge framework for teachers and teacher educators. ICT Integrated Teacher Education Models, 1-8. Retrieved from http://cemca.org.in/ckfinder/userfiles/files/ICT teacher education Module 1 Final_May 20.pdf 
Luhukay, M. S. (2013). Penerapan manajemen krisis di Indonesia: Memotret krisis dalam kacamata public relations. Scriptura, 2(1), 18-28. http://doi.org/10.9744/scriptura.2.1.18-28

Mardhiyani, N. L. (2014). Memahami pengalaman komunikasi warga multietnis. Jurnal IImu Komunikasi, 12(1), 16-25.

Mastuti, E. (2016). Pemanfaatan teknologi dalam menyusun evaluasi hasil belajar: Kelebihan dan kelemahan tes online untuk mengukur hasil belajar mahasiswa. Jurnal Penelitian Psikologi, 7(1), 10-19.

Nuredayu Omar. (2018). The relationship components of communication competence in the direct selling process in Malaysia. Jurnal Komunikasi: Malaysian Journal of Communication, 34(1), 37-54. http://doi.org/10.17576/JKMJC-2018-3401-03

Nuriyanti, D., Utami, N. R., \& Supriyanto. (2013). Pengembangan e-learning berbasis moodle sebagai media pembelajaran sistem gerak di SMA. Unnes Journal of Biology Education, 2(3). Retrieved from http://journal.unnes.ac.id/sju/index.php/ujeb

Nurtyasrini, S., \& Hafiar, H. (2016). Pengalaman komunikasi pemulung tentang pemeliharaan kesehatan diri dan lingkungan di Tpa Bantar Gebang. Jurnal Kajian Komunikasi, 4(2), 219-228. http://doi.org/10.24198/jkk.vol4n2.9

Picciano, A. G. (2017). Theories and frameworks for online education: Seeking an integrated model. Online Learning Journal, 21(3), 166-190. http://doi.org/10.24059/olj.v21i3.1225

Prihandini, P. (2016). Pengalaman komunikasi pemakaian jilbab fashionable. Jurnal Commed, 1(1), 51-68.

Rahardja, U., Lutfiani, N., Handayani, I., \& Suryaman, F. M. (2019). Motivasi belajar mahasiswa terhadap metode pembelajaran online ilearning + pada perguruan tinggi student learning motivation against ilearning + online learning method in higher education. Jurnal Sisfotenika, 9(2), 192-202.

Sa'diyah, H. (2013). Manajemen krisis Universitas Islam Indonesia (UII) Yogyakarta dalam mengatasi kasus Mapala UNISI. Journal of Chemical Information and Modeling, 53(9), 1689-1699. http://doi.org/10.1017/CBO9781107415324.004

Sari, P. (2015). Memotivasi belajar dengan menggunakan e-learning. Jurnal Ummul Qura, $\mathrm{VI}(2), 20-35$.

Sitompul, N. C. (2012). Perilaku komunikasi nonverbal guru dalam kelas pembelajaran: Maknanya bagi siswa SMA. Jurnal Pendidikan dan Pembelajaran, 19(44), 38-49. Retrieved from http://journal.um.ac.id/index.php/pendidikan-danpembelajaran/article/view/3122

Smith, R. D. (2005). Strategic planning for public relations. New Jersey: Laurence Erlbaum Associates Publishers.

Telaumbanua, D. (2020). Urgensi pembentukan aturan terkait pencegahan Covid-19 di Indonesia. QALAMUNA: Jurnal Pendidikan, Sosial, dan Agama, 12(01), 59-70. http://doi.org/10.37680/qalamuna.v12i01.290

Venus, A., \& Nabilah, D. (2016). Pengalaman komunikasi terapeutik perawat orang lanjut usia. Jurnal Communicate, 3(2), 75-86.

Wajdi, M. B. N., Kuswandi, I., Al Faruq, U., Zulhijra, Khairudin, \& Khoiriyah. (2020). Education policy overcome coronavirus, a study of Indonesians. EDUTEC : Journal of Education and Technology, 3(2), 96-106. http://doi.org/10.29062/edu.v3i2.42 
Watie, E. D. S. (2016). Komunikasi dan media sosial (Communications and social media). Jurnal The Messenger, 3(2), 69. http://doi.org/10.26623/themessenger.v3i2.270

Yayu, N., Hidayat, D., \& Suhadi, M. (2019). Pendekatan intercultural communication pada public relations PT Santos dalam membangun komunikasi empati. Jurnal Profesi Humas Universitas Padjadjaran, 4(1), 1-22.

Yunus, N. R., \& Rezki, A. (2020). Kebijakan pemberlakuan lock down sebagai antisipasi penyebaran corona virus Covid-19. SALAM: Jurnal Sosial dan Budaya Syar-I, 7(3). http://doi.org/10.15408/sjsbs.v7i3.15083 